\title{
The use of herbal medicine in a rural community in Vitoria da Conquista, Bahia, Brazil: an indication for pharmacological studies
}

\begin{abstract}
The present study evaluated ethno medicinal knowledge of people in the rural community of São Sebastião, Vitória da Conquista, Bahia, Brazil. Using semi-structured interviews, 84 randomly chosen individuals informed about the use of traditional medicinal plants in their community, thereby identifying their therapeutic potential, which were categorized according to the ICD-10 (International Statistical Classification of Diseases and Related Health Problems). The collected data were analyzed with using the Informant consensus factor (ICF), the Relative importance (RI) and the scores were calculated by using Fidelity level (FL). Forty-six species traditionally used in treatment of ailments were categorized as diseases: digestive system, respiratory problems, general symptoms/signs, nervous system and circulatory system. Lippia alba, Cymbopogon citratus and Foeniculum vulgare had a RI $>1$, indicating important value to the community. Highest values of FL were: Spondias purpurea, Bauhinia forficata, Punica granatum, Matricaria chamomilla, Stryphnodendron adstringens, Foeniculum vulgare, Mentha piperita, Amburana cearensis and Dysphania ambrosioides. S. purpurea, to treat hypertension, and Amburana cearensis (indigestion) deserve in depth pharmacological and toxicological studies so that they might be included in the National Program of Medicinal Plants and Phytotherapics of the Brazilian Sistema Único de Saúde and safely prescribed by regional health teams, lowering costs for local health system.
\end{abstract}

Keywords: ethnobotanical study, northeast brazil, traditional medicine, medicinal plants, spondias purpurea
Volume 7 Issue I - 2017

\author{
Gabriele Marisco,' Thalana SS Silva,' \\ Renata Assun, ${ }^{1,2}$ Martin Brende, ${ }^{1,2}$ Cristina \\ Pungartnik ${ }^{2}$ \\ 'Departamento Ciências Naturais, Universidade Estadual do \\ Sudoeste da Bahia, Brazil \\ ${ }^{2}$ Departamento Ciências Biológicas, Universidade Estadual de \\ Santa Cruz, Brazil
}

Correspondence: Cristina Pungartnik, Departamento Ciências Biológicas, Universidade Estadual de Santa Cruz, Laboratório de Biologia dos Fungos, Rodovia Ilhéus-Itabuna, Km-16, Salobrinho, Ilhéus, Bahia, Brazil,Tel 557336805438 ,

Email cpungartnik@yahoo.com.br

Received: February 20, 2017 | Published: May 17, 2017
Abbreviations: ICF, informant consensus factor; RI, relative importance; FL, fidelity level; UESB, universidade estadual do sudoeste da bahia, HUESBVC, herbarium at uesb, vitoria da conquista

\section{Introduction}

Brazil is a continental country with six different biomes, Amazon, Atlantic Forest, Cerrado, Caatinga, Pantanal and Pampa, ${ }^{1}$ of which 3 are represented in the State of Bahia (Atlantic Forest, Caatinga, Cerrado). ${ }^{2,3}$ Traditional knowledge of medicinal plants used by indigenous populations of rural areas of Bahia has not received enough attention so far, although in northeastern Brazil there are ethnobotanical studies recently published. ${ }^{4-8}$ Vitoria da Conquista, Bahia was formerly (18th Century) inhabited by the Indian tribes Mongoiós (subgroup Camacãs), Ymborés (or Aimorés) and to a lesser extent by the Pataxós. Their villages were scattered over a wide range, known as the Sertão da Ressaca. Today, the original vegetation cover in Vitória da Conquista does not exceed 10\%, consisting of Caatinga and Atlantic Forest biomes. ${ }^{9}$ This vegetation type is of fundamental importance for maintaining the quality of regional watersheds, such as Rio Mole, Rio Pardo and Rio Caculé (rivers) that benefit a large population of southwestern Bahia. ${ }^{10}$ The rural communities, mainly extinguished Brazilian natives (indigenous communities) own diverse knowledge about plants and caring for the environment. Thus, the need of research on communities and how they deal with plants so that their descendants acquire their traditional knowledge. ${ }^{11}$

Use of medicinal plants has grown considerably in the second half of the 20th century, from many parts of the world. In the developing countries $65-80 \%$ of the population depends exclusively on the medicinal plants for the basic healthcare, ${ }^{12}$ including Northeastern
Brazil. ${ }^{5}$ Brazil was considered the seventh largest market, and from 2006 to 2010 grew by $14 \%$ and it is also estimated that by 2015 Brazil will be the sixth largest market in this sector. ${ }^{13}$ Important policies were implemented in the last decade to encourage research and development related to the use of medicinal plants and herbal remedies which may be provided with quality, safety and efficacy to the population, prioritizing the country's biodiversity. ${ }^{14}$ Considering the actual worldwide popular use of medicinal plants, the Sistema Único de Saúde (SUS, Brazilian Health System), via the Brazilian Ministry of Health, has introduced the National Policy on Integrative and Complementary Practices and the National Policy on Medicinal Plants in $2006^{13,15}$ which lists some indications for the use of medicinal plants, such as Aloe vera L. (against psoriasis and burns), Salix alba L. (against backache) and Rhamnus purshiana DC. (to treat constipation). The increased prescription of medicinal plants via physicians of SUS has not only raised their consume in health care but has also helped to educate about possible dangers of their indiscriminate use. As prescription of local herbal medicines by qualified professionals and accurate information have increased and this will help to prevent medical application of unsafe and ineffective plants. ${ }^{16,17}$

Different tools to quantify ethno botanical data are applied in complementing studies of plant usage in folk medicine. Thus, collection of quantitative data could support the conservation of certain plant species and knowledge of their popular medical use, mainly by informing about species with several therapeutic indications. ${ }^{18,19}$ Some of these tools have been successful in identifying the pharmacological potential of medicinal plants, thus enabling their effective application in herbal medicine. ${ }^{20-22}$ The present study evaluated the ethno medicinal knowledge of the people in the community of São Sebastião, Vitória da Conquista, Bahia, using ethno botanical tools in order to 
provide baseline information for future ethno pharmacological and phytochemical studies.

\section{Materials and methods}

\section{Study area}

The study area is located in the state of Bahia and the survey was conducted in the village of São Sebastião, which belongs to the city of Vitória da Conquista ( $14^{\circ} 47^{\prime} \mathrm{S}$ and $40^{\circ} 39^{\prime} \mathrm{W}$ ). São Sebastião is a small rural community of 2,730 inhabitants $(1,325$ men and 1,405 women, average monthly income of U\$280), to whom the use of medicinal plants may not only be a tradition but also an economic necessity; indeed, this area still hosts many Brazilian native plants, which are worth thorough study and protection, as elsewhere in Brazil. ${ }^{23,24}$ Figure 1 shows the detailed location map of the study area

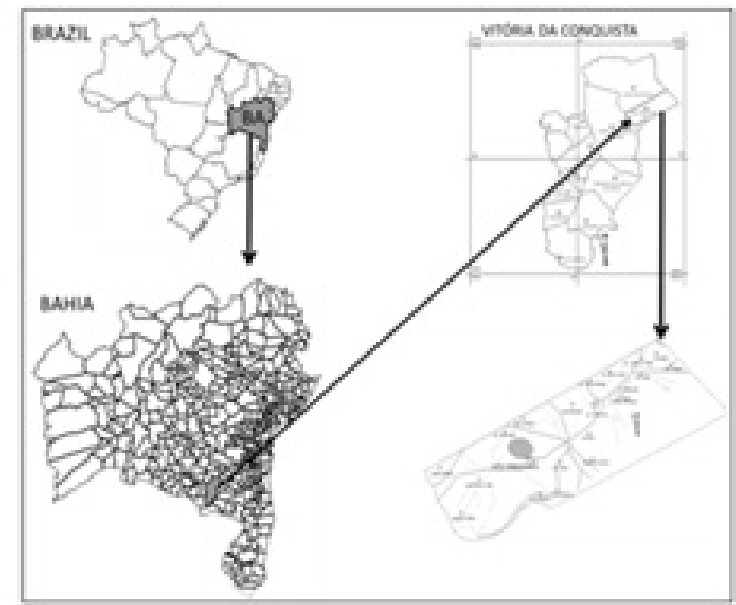

Figure I Location of the study area, village of São Sebastião, Vitória da Conquista, Bahia, Brazil.

\section{Ethnobotanical survey}

Data were collected during 2012 to 2014. Participants signed the Term of Free and Clarified Assent (demanded by the National Health Council through the Ethics and Research Committee, Resolution 196/96 of the CNS/MS). The study was approved by the Committee of Ethics in Research with Human Beings (CEP) of the State University of Southwestern Bahia (Universidade Estadual do Sudoeste da Bahia-UESB) ( $N^{\circ}$ 0134.0.454.000.11). Data of the semi-structured questionnaires informed on the respondents profile and knowledge about plants used in medicinal therapy, how the knowledge was acquired, plants frequently used by that community and their common therapeutic indications. The cited regional plant species were collected, identified and integrated into the collection of the herbarium at UESB, Vitoria da Conquista (HUESBVC).

\section{Data analysis}

The citations for therapeutic purposes were classified according to ICD-10 (International Statistical Classification of Diseases and Related Health Problems) established by World Health Organization. ${ }^{25}$ The Informant Consensus Factor (ICF) was calculated for each ailment category to identify the agreements of the informants on the reported cures for the group of diseases. ${ }^{26}$ The Relative Importance Value (RI), a measure of the diversity of medicinal applications, was calculated for each medicinal plant cited by informants. ${ }^{27}$ The highest possible RI value (2.0) indicates the species with the highest diversity of medicinal use. Scores were calculated Fidelity Level (FL). ${ }^{28}$

\section{Results and discussion}

\section{Socio-demographic information}

Eighty-four (84) community residents were interviewed $(83.3 \%$ women aged between 18 and 80years, half declaring themselves "housewives") representing 84 families of whom $96 \%$ used medicinal plants to treat different diseases. In regard to the level of schooling, $10.8 \%$ were illiterate, $63.1 \%$ of respondents did not complete elementary school, $11.8 \%$ did not complete secondary school and $14.3 \%$ completed secondary school.

\section{Acquisition, parts used and mode of preparation of medicinal plants}

Table 1 reports 46 medicinal plants belonging to 30 families. This survey showed that some $80 \%$ of the species with medicinal properties were cultivated in orchards or gardens in backyards of the houses; $15 \%$ are considered wild and extracted from the surrounding environments and $5 \%$ of the plants were bought at popular markets or drugstores, demonstrating the importance of cultivation as the main source of medicinal plants. Several authors in similar ethnopharmacological studies have also reported that the majority of respondents acquired plants grown in their own backyard cultivars. ${ }^{20,24}$ The leaves $(78.2 \%)$ were the most frequently used plant part for the treatment of diseases, followed by root (8.2\%) and seed (6.4\%) (Figure 2), which corroborated similar results found in other ethnobotanical studies. ${ }^{29,30}$ In many parts of Brazil the use of teas is a common practice. The main preparation methods of the plants cited were by decoction $(69.3 \%)$, boiling plant material in water, and infusion $(21.2 \%)$, which is worrying since infusion is used to prepare all tender parts of medicinal plants such as leaves, buttons and flowers, rich in volatile components, delicate aromas and active principles, degraded by the action of water and heat. ${ }^{31}$

\section{Ailments treated by medicinal plants}

Respondents were asked to associate a medicinal plant with possible health care indications, according to $\mathrm{WHO} .{ }^{24,32}$ The highest number of citations (106) was for digestive system, while the highest ICF value was obtained for nervous problems (0.85) and digestive system $(0.84)$. Values for nine common diseases categories are given in Table 2. Most cited were those categories related to the digestive system $(32.8 \%)$, followed by respiratory diseases $(17 \%)$, general symptoms/signs of inflammation $(14.5 \%)$, nervous system $(13.3 \%)$ and circulatory system diseases (12.6\%). Similar results were already found in other studies ${ }^{20,24,33,34}$ indicating that the residents of São Sebastião use medicinal plants as the first line of treatment for most common diseases.

\section{Use and efficacy of the medicinal plants}

Species with high value of RI $(>1)$ are used to treat a variety of diseases and are therefore considered important to a community. ${ }^{27}$ Lippia alba with $\mathrm{RI}=2$ was the most versatile species in relation to its use and was indicated for cures of up to 6 body systems, followed by Cymbopogon citratus and Foeniculum vulgare (Table 3). All plants with RI $>1$ through this methodology assume that a plant is important when it is most versatile; they are measures of folk knowledge and interpretations of their use must be carefully made. ${ }^{4}$ The data indicated that some plants have more diversified medicinal uses or applications than others..$^{35}$ Among all plants, Lippia alba with $R I=2$ was the most versatile species in relation to its use and has often been reported in ethnobotanical studies ${ }^{36}$ and pharmacological use, for example, vasorelaxant effect, ${ }^{37}$ action as a tranquilizer ${ }^{38}$ and effective 
at preventing gastric ulceration..$^{39}$ However, when the objective is the search for new plant-derived drugs, the concordance of the answers as to the medicinal use of a particular plant is extremely important. Plants indicated for many different applications would have less credibility compared to those with a higher fidelity of use..$^{33}$ Plants with relatively high level of concordance, i.e., with multiple informants agreeing on their therapeutic value, suggest a real efficacy in disease treatment. ${ }^{28}$

Table I List of traditional medicinal plants investigated in this study with their related information

\begin{tabular}{|c|c|c|c|c|c|}
\hline Voucher & Scientific name & Family & Popular name brazil & Part plant indicated & preparation \\
\hline 6453 & $\begin{array}{l}\text { Dysphania ambrosioides (L) } \\
\text { Mosyakin \& Clemants }\end{array}$ & Amaranthaceae & Mastruz & Root, leaves & $\begin{array}{l}\text { Juice, infusion, decoction, } \\
\text { maceration (cutaneous) }\end{array}$ \\
\hline 8010 & Allium sativum $L$ & Amaryllidaceae & Alho & Bulb & Decoction, juice, infusion \\
\hline 6452 & Spondias purpurea $L$ & Anacardiaceae & Seriguela & Leaves & Decoction \\
\hline 6377 & Foeniculum vulgare Mill. & Apiaceae & Erva doce & Leaves, seed & Infusion, decoction \\
\hline 8008 & Lepidium virginicum $L$. & Brassicaceae & Agrião & Leaves & Syrup \\
\hline 8007 & Ananas comosus (L.) Merr. & Bromeliaceae & Abacaxi & Fruit & Decoction \\
\hline 8018 & Matricaria chamomilla L. & Compositae & Camomila & Flower & Infusion \\
\hline 7994 & Bidens pilosa $L$. & Compositae & Carrapicho de agulha & Root & Infusion, decoction \\
\hline 8012 & Solidago microglossa DC.? & Compositae & Arnica & Leaves & Infusion \\
\hline 7999 & Baccharis trimera (Less.) DC. & Compositae & Carqueja & Leaves & Decoction \\
\hline 8019 & Costus sp. & Costaceae & Cana dágua & Leaves & Decoction \\
\hline 8040 & Cucumis sativus $L$. & Cucurbitaceae & Pepino & Fruit & Juice \\
\hline 7989 & Sechium edule (Jacq.) Sw. & Cucurbitaceae & Chuchu & Leaves & Decoction \\
\hline 8030 & Eleocharis sp. & Cyperaceae & Junça & Root & Decoction \\
\hline 8037 & Aleurites moluccanus (L.) Willd & Euphorbiaceae & Nogueira & Seed & Maceration \\
\hline 8045 & - & Lamiaceae & Tioioiô & Leaves & Decoction \\
\hline 6459 & Plectranthus barbatus Andrews & Lamiaceae & Boldo & Leaves & Infusion, decoction, juice \\
\hline 8002 & Mentha spicata $L$. & Lamiaceae & Hortelãzinho & Leaves & Syrup, infusion, decoction \\
\hline 8028 & $\begin{array}{l}\text { Plectranthus amboinicus } \\
\text { (Lour.) Spreng. }\end{array}$ & Lamiaceae & Hortelã grosso & Stem, leaves, root & Syrup, decoction \\
\hline 8005 & Ocimum basilicum L. & Lamiaceae & Alfavaca & Leaves & Syrup, infusion \\
\hline 8009 & Rosmarinus officinalis $L$. & Lamiaceae & Alecrim & Leaves & Decoction, syrup \\
\hline 8041 & Mentha sp. & Lamiaceae & Poejo & Leaves & Infusion \\
\hline 8006 & Persea americana Mill. & Lauraceae & Abacate & Leaves & Juice \\
\hline 8043 & Senna sp. & Leguminosae & Sene & Leaves & Infusion \\
\hline 8014 & $\begin{array}{l}\text { Stryphnodendron adstringens } \\
\text { (Mart.) Coville }\end{array}$ & Leguminosae & Barbatimão & Root, leaves, bark & Infusion, decoction \\
\hline 8046 & $\begin{array}{l}\text { Amburana cearensis } \\
\text { (Allemao) A.C.Sm }\end{array}$ & Leguminosae & $\begin{array}{l}\text { Umburana macho, } \\
\text { Umburana, amburana, } \\
\text { amburana-de- cheiro, } \\
\text { imburana, cerejeira-rajada. }\end{array}$ & Seed, bark & Infusion, decoction \\
\hline 8038 & Bauhinia forficata Link & Leguminosae & Pata de vaca & Leaves & Infusion, decoction \\
\hline 6460 & Punica granatum $L$. & Lythraceae & Romã & Leaves & Infusion, decoction \\
\hline 6461 & Malpighia emarginata $D C$. & Malpighiaceae & Acerola & Leaves & Juice \\
\hline 8022 & Dorstenia sp. & Moraceae & Contra- erva & Root & Decoction \\
\hline 8036 & Myristica fragrans Houtt & Myristicaceae & Nós moscada & Seed, fruit & Juice, decoction \\
\hline 7996 & Eugenia uniflora $L$. & Myrtaceae & Pitanga & Leaves & Decoction \\
\hline 8024 & Eucalyptus sp. & Myrtaceae & Eucalipto & Leaves & Infusion, decoction \\
\hline 8021 & Averrhoa carambola $L$. & Oxalidaceae & Carambola & Leaves & Infusion \\
\hline 8033 & Passiflora edulis Sims & Passifloraceae & Maracujá & Leaves & Infusion, decoction \\
\hline 8042 & $\begin{array}{l}\text { Phyllanthus heteradenius } \\
\text { Müll.Arg. }\end{array}$ & Phyllanthaceae & Quebra-pedra & Root, stem, leaves & Decoction \\
\hline 8044 & Plantago major $L$. & Plantaginaceae & Transagem & Leaves, root & Infusion, decoction \\
\hline 6384 & $\begin{array}{l}\text { Cymbopogon citratus } \\
\text { (DC.) Stapf. }\end{array}$ & Poaceae & Capim santo & Leaves, root & $\begin{array}{l}\text { Infusion, decoction, } \\
\text { inhalation, juice }\end{array}$ \\
\hline 8029 & Genipa americana $L$. & Rubiaceae & Genipapo & Fruit & Juice \\
\hline 8032 & Citrus limon (L.) Osbeck & Rutaceae & Limão & Leaves, fruit & Decoction, juice \\
\hline 8031 & Citrus sinensis (L.) Osbeck & Rutaceae & Laranja & Leaves & Decoction \\
\hline 8013 & Ruta graveolens $L$ & Rutaceae & Arruda & Leaves & Maceration \\
\hline 8017 & Solanum melongena $L$ & Solanaceae & Beringela & Fruit & Juice \\
\hline 7995 & Lippia alba (Mill.) N.E. Brown & Verbenaceae & Erva-cidreira & Leaves, seed, root & Infusion, decoction \\
\hline 8016 & Aloe vera L.Burm.f. & Xanthorrhoeaceae & Babosa & Leaves & Scraping, topic contact \\
\hline 8026 & Zingiber officinale Roscoe & Zingiberaceae & Gengibre & Root & Decoction \\
\hline
\end{tabular}


Table 2 Informant consensus factor (ICF) by category of diseases. (ICF is the number of use citations in each category minus the number of species used, divided by the number of use citations in each category minus one).

\begin{tabular}{llll}
\hline Category & Species & Citations & ICF \\
\hline Nervous system & 7 & 43 & 0.85 \\
Digestive system & I7 & 106 & 0.84 \\
Respiratory diseases & 17 & 55 & 0.70 \\
Circulatory system diseases & 13 & $4 I$ & 0.70 \\
General symptoms/signs ${ }^{\mathrm{a}}$ & $\mathrm{I}$ & 47 & 0.65 \\
Endocrine disorders $_{\text {Genitourinary diseases }}$ & 4 & 8 & 0.57 \\
Skin ailments & $\mathrm{I}$ & $\mathrm{I}$ & 0.30 \\
Neoplasias & 3 & 5 & 0.5 \\
Infectious diseases & $\mathrm{I}$ & $\mathrm{I}$ & 0 \\
Diseases of the musculoskeletal system & $\mathrm{I}$ & $\mathrm{I}$ & 0 \\
Diseases of the ear & $\mathrm{I}$ & $\mathrm{I}$ & 0 \\
\end{tabular}

${ }^{a}$ symptoms and signs such as stomachache, inflammation, infection, fever, headache, malaise

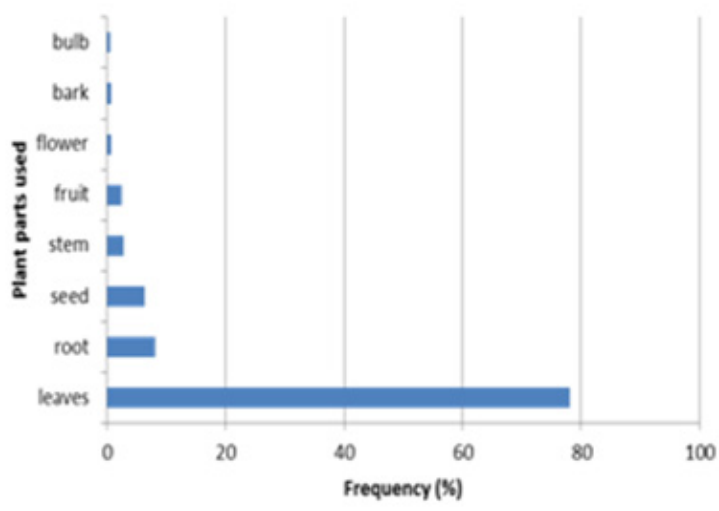

Figure 2 Plant parts used for treating diseases/disorders.

In order to find therapeutically potent plants for chemical screening, the Fidelity Level (FL) values of 16 medicinal plants (Table 4) were cited by three or more informants. Two plants were obtained: Spondias purpurea and Bauhinia forficata, with the highest $(100 \%)$ FL values for hypertension and diabetes respectively. The species that gave the highest fidelity level values are considered more promising candidate plants for further pharmacological investigations and deserve priority attention. ${ }^{35}$ Most plants mentioned in the study, for example, Bauhinia forficata, Punica granatum, Matricaria chamomilla and Stryphnodendron adstringens showed high FL, as expected, since literature has plenty of ethnopharmacological studies related to them. However, the plants which mentioned high FL, Spondias purpurea and Amburana cearensis, are suggested for further study. Spondias purpurea was cited for only one treatment (hypertension, 100\%), it is exotic (not originally native from Brazil), though it is widely used in northeastern Brazil. Amburana cearensis (indigestion, 55.5\%) is native from Brazil and has few published information for a therapeutic target, furthermore it has been reported in other studies ethnobotanical. ${ }^{12,32}$ Therefore, these species are promising candidates for pharmacological studies.

\section{Comparison of outstanding medicinal plants with the literature and other studies}

Comparison of the pharmacological literature published in different countries with the present ethnobotanical data showed that many of the plants have earlier been reported to have activities against specific diseases. Examples include Bauhinia forficata, used to treat diabetes, and Allium sativum, used to treat hypertension problems. Such observations hinted at the fidelity of the reports by the residents of São Sebastião, confirming that this knowledge has been preserved as in other communities. Whereas other medicinal plants are used differently, when compared to other traditional practices, for example Amburana cearensis was used against indigestion, but it was mentioned in other studies for antibacterial activity, to treat rheumatism, cold, sinusitis ${ }^{40}$ and as anti-inflammatory ${ }^{41}$ (Table 5). There is also a species used in this study, Spondias purpurea, but not mentioned in the literature for its medicine purpose.

Comparing this study to other ethnobotanical studies on traditional medicinal plants in Northeastern Brazil, although with areas of study in different proportions and methods of research, it was possible to observe that considerable similarity exists with respect to categories of cited diseases (problems of the respiratory system, digestive system, circulatory system). ${ }^{4,5}$ According to this study, Amburana cearensis and Bauhinia sp are the most common medicinal plants in Northeastern Brazil cited in ethnobotanical surveys. $5,6,12,23,18$

Table 3 Relative importance (RI) values for medicinal plants used against specific ailments.

\begin{tabular}{|c|c|c|c|}
\hline Species & Relative importance & Origin* & categories \\
\hline Lippiaalba & 2.0 & Native & $\begin{array}{l}\text { Diseases of the nervous system, genitourinary system, circulatory system, diseases, } \\
\text { respiratory system, symptoms and signs involving the digestive system and the abdomen, } \\
\text { general signs and symptoms }\end{array}$ \\
\hline Cymbopogon citratus & 1.87 & Exotic & $\begin{array}{l}\text { Diseases related to the respiratory system, circulatory and nervous, symptoms and signs } \\
\text { involving the digestive system and the abdomen, diseases of the genitourinary system, } \\
\text { general signs and symptoms }\end{array}$ \\
\hline Foeniculum vulgare & 1.43 & Exotic & $\begin{array}{l}\text { Diseases, symptoms and signs involving the digestive system and abdomen, diseases of } \\
\text { the nervous system, diseases of the circulatory system, categories general signs and } \\
\text { symptoms, , diseases of the genitourinary system }\end{array}$ \\
\hline Aloevera & 0.59 & Exotic & $\begin{array}{l}\text { Neoplasias, diseases of the skin, symptoms and signs involving the digestive system and the } \\
\text { abdomen, categories general signs and symptoms }\end{array}$ \\
\hline Mentha spicata & 0.83 & Exotic & $\begin{array}{l}\text { Diseases digestive system and abdomen, diseases respiratory system, diseases of the } \\
\text { genitourinary system }\end{array}$ \\
\hline Dysphania ambrosioides & 0.80 & Native & $\begin{array}{l}\text { Diseases, symptoms and signs involving the digestive system and abdomen, Diseases } \\
\text { related to the respiratory system, general symptoms and signs, diseases of the skin }\end{array}$ \\
\hline Myristica fragrans & 0.59 & Native & $\begin{array}{l}\text { Symptoms and signs involving the digestive system and the abdomen, general signs and } \\
\text { symptoms, diseases of the circulatory system }\end{array}$ \\
\hline Punica granatum & 0.57 & Exotic & Categories respiratory, digestive and genitourinary systems \\
\hline Passiflora edulis & 0.54 & Native & Categories nervous system, circulatory, endocrine, nutritional and metabolic diseases \\
\hline
\end{tabular}


Table Continued...

\begin{tabular}{|c|c|c|c|}
\hline Species & Relative importance & Origin* & categories \\
\hline Amburana cearensis & 0.51 & Native & Diseases digestive system and abdomen, general signs and symptoms \\
\hline Plectranthus barbatus & 0.45 & Exotic & Diseases digestive system and abdomen, general signs and symptoms \\
\hline Plectranthus amboinicus & 0.43 & Exotic & Diseases respiratory system, infectious diseases \\
\hline Alliumsativum & 0.39 & Exotic & Respiratory diseases, diseases of the circulatory system \\
\hline $\begin{array}{l}\text { Stryphnodendron } \\
\text { adstringens }\end{array}$ & 0.37 & Native & Categories general signs and symptoms, genitourinary, and skin diseases \\
\hline Citrus limon & 0.37 & Exotic & Respiratory diseases, diseases of the circulatory system \\
\hline Bauhinia forficata & 0.24 & Native & Diseases of the circulatory system, endocrine, nutritional and metabolic diseases \\
\hline Matricaria chamomilla & 0.19 & Exotic & Diseases of the nervous system \\
\hline Ocimum basilicum & 0.19 & Exotic & Respiratory diseases, diseases of the circulatory system \\
\hline Spondias purpurea & 0.18 & Exotic & Diseases of the circulatory system \\
\hline
\end{tabular}

(RI=NP+NCS) where NP is obtained by dividing the number of properties (reported specific ailments) attributed to a species divided by the total number of properties attributed to the most versatile species (species with the highest number of properties). NBS is the number of body systems (ailment categories) treated by a given species divided by the total number of body systems treated by the most versatile species). Medicinal plant species used by community residents of Vitória da Conquista, recorded three or more times.

*All plants not originally native from Brazil were considered exotic

Table 4 Fidelity level (FL) values of medicinal plants cited by three or more informants. FL= (Ip/lu $x \mid 00)$, where Ip is the number of informants who independently indicated the use of a species for the same major ailment and lu the total number of informants who mentioned the plant for any major ailment

\begin{tabular}{lllll}
\hline Scientific names & Category & Ip & Iu & FL (\%) \\
\hline Spondias purpurea & Hypertension & 6 & 6 & 100 \\
Bauhinia forficate & Diabetes & 5 & 5 & 100 \\
Punica granatum & Sore throat & 3 & 4 & 75 \\
Matricaria chamomilla & Tranquilizer & 2 & 3 & 66,6 \\
Stryphnodendron adstringens & Inflammation & 2 & 3 & 66,6 \\
Foeniculum vulgare & Flatulence & 20 & 34 & 58,8 \\
Mentha spicata & Influenza & 10 & 17 & 58,8 \\
Amburana cearensis & Indigestion & 5 & 9 & 55,5 \\
Dysphania ambrosioides & Inflammation & 5 & 9 & 55,5 \\
Myristica fragrans & Headache & 2 & 4 & 50 \\
Allium sativum & Hypertension & 2 & 4 & 50 \\
Aloe vera & Skin diseases & 2 & 4 & 50 \\
Plectranthus amboinicus & Influenza & 3 & 6 & 50 \\
Plectranthus barbatus & Indigestion & 3 & 7 & 42,8 \\
Lippia alba & Flatulence & 19 & 57 & 33,3 \\
Cymbopogon citratus & Hypertension & 17 & 54 & 31,4 \\
\hline
\end{tabular}

Table 5 Comparison of the uses of medicinal plants recorded with information gathered from the literature

\begin{tabular}{|c|c|c|c|}
\hline Scientific Name & $\begin{array}{l}\text { Ailments recorded in } \\
\text { the present Study }\end{array}$ & $\begin{array}{l}\text { Main use in the } \\
\text { Present Study }\end{array}$ & Some medicines uses reported in the literature \\
\hline Alliumsativum & $\begin{array}{l}\text { Influenza and } \\
\text { hypertension }\end{array}$ & Hypertension & $\begin{array}{l}\text { Antifungal, antibacterial, antitumor, anti-inflammatory, antithrombotic, }{ }^{42} \\
\text { anti-hypertensive, }{ }^{43} \text { attenuated left ventricular diastolic dysfunction } \\
\text { and fibrosis without significantly decreasing systolic blood pressure in } \\
\text { hypertensive rats }{ }^{44}\end{array}$ \\
\hline Aloevera & $\begin{array}{l}\text { Hair loss, stomachache, } \\
\text { skin inflammation, cancer, } \\
\text { ulcer }\end{array}$ & Skin diseases & $\begin{array}{l}\text { Lowering LDL, increasing HDL, decreasing blood glucose level, treating } \\
\text { genital herpes and psoriasis, }{ }^{45} \text { positive effect on body mass, caecum and } \\
\text { tibial bones in the short term }{ }^{46} \text { anti-inflammatory activity. }{ }^{47}\end{array}$ \\
\hline Amburana cearensis & $\begin{array}{l}\text { Headache, stomach } \\
\text { problems, ulcer, intestinal } \\
\text { Infection }\end{array}$ & Indigestion & $\begin{array}{l}\text { Used to treat rheumatism, cold, and sinusitis } .{ }^{40} \text {, anti-inflammatory, }{ }^{41} \\
\text { antibacterial activity }{ }^{48,49}\end{array}$ \\
\hline Bauhinia forficata & Diabetes & Diabetes & $\begin{array}{l}\text { Antidiabetic activity, }{ }^{50} \text { hypoglycemic activity, }{ }^{51} \text { antioxidant activity, } \\
\text { beneficial in the prevention of diabetes complications associated with } \\
\text { oxidative stress }{ }^{52}\end{array}$ \\
\hline Cymbopogoncitratus & $\begin{array}{l}\text { Hypertension, tranquilizer, } \\
\text { cramps, stomach } \\
\text { problems, influenza, } \\
\text { headaches }\end{array}$ & Hypertension & $\begin{array}{l}\text { Cardio protective potential is mainly because of its antioxidant activity, }{ }^{53} \\
\text { antispasmodic, hypotensive, anticonvulsant, analgesic, antiemetic, } \\
\text { antitussive, antirheumatic, antiseptic and treatment for nervous and } \\
\text { gastrointestinal disorders and fevers, }{ }^{54} \text { antioxidant activity, antidiabetic } \\
\text { activity, }{ }^{55} \text { anti-hypertensive } .^{56}\end{array}$ \\
\hline Dysphania ambrosioides & $\begin{array}{l}\text { Inflammation, toothache, } \\
\text { scarring, ulceration, } \\
\text { infection }\end{array}$ & Inflammation & $\begin{array}{l}\text { Antitumor effect, }{ }^{57} \text { anti-inflammatory activity } .{ }^{58} \text {, antifungal activity, }{ }^{59} \\
\text { amoebicidal activity }{ }^{60}\end{array}$ \\
\hline
\end{tabular}


Table Continued...

\begin{tabular}{lll}
\hline Scientific Name & $\begin{array}{l}\text { Ailments recorded in } \\
\text { the present Study }\end{array}$ & $\begin{array}{l}\text { Main use in the } \\
\text { Present Study }\end{array}$
\end{tabular}

Lippiaalba

Matricaria chamomilla

Tranquilizer and insomnia Tranquilizer

Mentha spicata

Myristica fragrans

Plectranthus amboinicus

Influenza, cough, worms Influenza

Stomach problems

(indigestion, nausea,

Plectranthus barbatus vomiting, stomach pain, hangover)

Sore throat, stomach

Punicagranatum

Spondias purpurea problems, uterine problems

Hypertension

Tranquilizer
Sedative, anxiolytic activities, ${ }^{64}$ antibacterial, antifungal, ${ }^{65}$ vasorelaxant effect was evaluated in vitro in rat superior mesenteric artery rings ${ }^{37}$

Decreased stress in bovines, associated with inhibition of cortisol production and calming and anxiolytic effects ${ }^{66}$ sleep aid, sedation ${ }^{67}$ induce recovery from a polycystic ovary syndrome induced state in rats, but also increase dominant follicles, better endometrial tissue arrangements can be regarded as another therapeutic effect ${ }^{68}$ protective effects on paraquat-induced damage via oxidative stress in rat lung. ${ }^{69}$

Effective inhibitor of LPS-induced inflammation $7^{0}$ antioxidant effects ${ }^{71}$ effective for antiemetic treatment ${ }^{72}$

Extracts of nutmeg showed a good antidiarrheal effect, with a significant sedative property. ${ }^{73}$

The aqueous extract has the analgesic and anti-inflammatory abilities,,$^{74,75}$ for diabetes, which may be due to the presence of flavonoids ${ }^{76}$ exhibited antioxidant, diuretic, anti-inflammatory, cytotoxic and antimicrobial activities, ${ }^{77}$ effectiveness against methicillinresistant Staphylococcus aureus skin abscesses, ${ }^{78}$ treatment of rheumatoid arthritis $^{79}$

The plant is also used to treat gastritis and intestinal spasms, ${ }^{80}$ stomach pain, nausea, vomiting and is used as purgatives, carminatives and as anthelmintic ${ }^{81}$ antioxidant activity ${ }^{82}$

Wound healing activity.$^{83}$,anti-inflammatory effects ${ }^{84}$ might be used as an antibacterial agent in controlling oral infections ${ }^{85}$

Antimicrobial activities, ${ }^{86}$ antioxidant activity ${ }^{87}$

Anti-inflammatory activity ${ }^{88}$ antibacterial activity ${ }^{89,90}$ antifungal activity, ${ }^{91}$ reducing bacterial.$^{92}$, tyrosinase inhibitory activity, ${ }^{93}$ in the treatment of leucorrhea, gonorrhea, gastritis, diarrhea, bleeding, and wound healing ${ }^{94}$

\section{Conclusion}

Ethnobotanical studies in rural areas in Bahia, Brazil, are rare and, when available published in local reports, Brazilian journals or part of Governmental technical reports available mainly in Portuguese, these may contribute to perpetuate local knowledge far from the light of scientific knowledge. Additionally, more studies like this should be done in Bahia, by the cultural and biological diversity, and because it is the biggest state of Northeastern Brazil. The results presented here indicated that medicinal plants are commonly used by São Sebastião rural population, a total of 46 species were documented, the main indications for medicinal plant use were against digestive system, circulatory system and respiratory diseases and of general symptoms/ signs of inflammation. This evidences that the knowledge on the use of medicinal plants in this region has been preserved, since $80 \%$ of the species with medicinal properties were cultivated in the houses.

In regard to future studies, it is suggested that plants with high FL deserve attention for pharmacological studies, phytochemical, toxicological and clinical trials so that they might be included in the National Program of Medicinal Plants and Phytotherapics of the Brazilian Sistema Único de Saúde and safely prescribed by regional health teams, because there are still few plants in listed in this program. Thus, this work aimed to contribute in the long-run to improved health care in the regions of study, preservation of local knowledge, as well as search for pharmacologically principles from plants.

\section{Acknowledgements}

Work was supported by UESB. GMS was a doctoral student in RENORBIO post-graduation program. We thank Profesor Avaldo Soares Filho from UESB for kindly identifying the plants.

\section{Conflicts of interest}

Author declares there are no conflicts of interest.

\section{Funding}

None.

\section{References}

1. Melo J, Santos A, Amorim E, et al. Medicinal plants used as antitumor agents in Brazil: an ethnobotanical approach. Evid Based Complement Alternat Med. 2011;2011:365-359.

2. Rodal MJ, Barbosa MR, Thomas WW. Do the seasonal forests in northeastern Brazil represent a single floristic unit? Braz J Biol. 2008;68(3):467-475.

3. Leal I, Silva J, Tabarelli M, Lacher T. Changing the course of biodiversity conservation in the caatinga of northeastern Brazil. Conserv Biol. 2005;19(3):701-706. 
4. Almeida C, Amorim E, Albuquerque U, et al. Medicinal plants popularly used in the Xingó region a semi-arid location in Northeastern Brazil. $J$ ethnobiol ethnomed. 2006;2:1-15.

5. Albuquerque U, Muniz de Medeiros P, Almeida A, et al. Medicinal plants of the caatinga (semi-arid) vegetation of NE Brazil: a quantitative approach. J Ethnopharmacol. 2007;114(3):325-354.

6. Ferreira Junior W, Siqueira C, Albuquerque U. Plant stem bark extractivism in the Northeast semiarid region of Brazil: A new aport to utilitarian redundancy model. Evid Based Complement Alternat Med. 2012;2012:1-11.

7. Cruz M, Medeiros P, Combariza IS, et al. I eat the manofê so it is not forgotten: local perceptions and consumption of native wild edible plants from seasonal dry forests in Brazil. J Ethnobiol Ethnomed. 2014;10(45):1-11.

8. Lozano A, Araújo E, Medeiros M, et al. The apparency hypothesis applied to a local pharmacopoeia in the Brazilian northeast. J ethnobiol ethnomed. 2014;10(2):1-17.

9. Santos J, Santos N, Santos M, et al. Honey classification from semi-arid, atlantic and transitional forest zones in Bahia, Brazil. J Braz Chem Soc. 2008;19(3):502-508.

10. IBGE. Instituto Brasileiro de Geografia e Estatística, Brazil. 2014.

11. http://www.cidades.ibge.gov.br/painel/historico.php?lang=\&codmun $=293330 \&$ search $=$ bahia $\% 7$ Cvitoria-da-conquista $\% 7$ Cinfograficos: historico

12. Cruz da Cunha L, Albuquerque U. Quantitative ethnobotany in an atlantic forest fragment of northeastern Brazil: implications to conservation. Environ Monit Assess. 2006;114(1):1-25.

13. Agra M, Freitas P, Barbosa-filho J. Synopsis of the plants known as medicinal and poisonous in Northeast of Brazil. Braz J Pharmacog. 2007;17(1):114-140.

14. Braun E, Alves L, Soares M, et al. Technological forecasting on phytotherapics development in Brazil. International Journal of Medical, Health, Pharmaceutical and Biomedical Engineering. 2012;6(7):14-18.

15. Christo A, Bruni RG, Araújo F, et al. Evidence for conservation and sustainable use in a fragment of the Atlantic forest in southeastern Brazil by a traditional human group. SpringerPlus. 2012;1:1-12.

16. Antonio G, Tesser C, Pires RM. Phytotherapy in primary health care. Rev Saúde Pública. 2014;48(3):541-553.

17. Bruning M, Mosegui G, Vianna C. The use of phytotherapy and medicinal plants in primary healthcare units in the cities of Cascavel and Foz do Iguaçu-Paraná: the viewpoint of health professionals. Cien Saude Colet. 2012;17(10):2675-2685.

18. Christo A, Guedes-Bruni R, Silva A. Local knowledge on medicinal plant gardens in a rural community near the Atlantic Rain Forest, southeastern Brazil. Braz J Pharmacog. 2010;20(4):494-501.

19. Silva H, Caraciolo R, Marangon L, et al. Evaluating different methods used in ethnobotanical and ecological studies to record plant biodiversity. J ethnobiol ethnomed. 2014;10(1):48.

20. Phondani P, Bhatt A, Elsarrag E, et al. Ethnobotanical magnitude towards sustainable utilization of wild foliage in Arabian Desert. $J$ Tradit Complement Med. 2016;6(3):209-218.

21. Baptista M, Ramos M, Albuquerque U,et al. Traditional botanical knowledge of artisanal fishers in southern Brazil. J ethnobiol ethnomed. 2013;9:54.

22. Chinsembu C. Ethnobotanical Study of Plants Used in the Management of HIV/AIDS-Related Diseases in Livingstone, Southern Province, Zambia. Evid Based Complement Alternat Med. 2016;2016:1-14.

23. Tufts H, Harris C, Bukania Z, et al. Antioxidant and anti-inflammatory activities of kenyan leafy green vegetables, wild fruits, medicinal plants with potential relevance for kwashiorkor. Evid Based Complement Alternat Med. 2015;2015:1-10.

24. Albuquerque U, Sousa Araújo T, Ramos M, et al. How ethnobotany can aid biodiversity conservation: reflections on investigations in the semiarid region of NE Brazil. Biodivers Conserv. 2009;18(1):127-150.

25. Zank S, Hanazaki N. Exploring the Links between ethnobotany, local therapeutic practices, and protected areas in Santa Catarina coastline, Brazil. Evid Based Complement Alternat Med. 2012;2012:15.

26. WHO. International Statistical Classification of Diseases and Related Health Problems. 2011.

27. Heinrich M, Ankli A, Frei B, et al. Medicinal plants in Mexico: healers' consensus and cultural importance. Soc Sci Med. 1998;47(11):1859-1871.

28. Bennett B, Prance G. Introduced plants in the indigenous pharmacopoeia of northern south America. Econ Bot. 2000;54(1):90-102.

29. Friedman J, Yaniv Z, Dafni A, et al. A preleminary classification of the healing potential of medicinal plants, based on a rational analysis of an ethnopharmacological field survey among bedouins in the Negev desert, Israel. J Ethnopharmacol. 1986;16(2-3):275-287.

30. Afolayan A, Grierson D, Mbeng W. Ethnobotanical survey of medicinal plants used in the management of skin disorders among the Xhosa communities of the Amathole District, Eastern Cape, South Africa. $J$ Ethnopharmacol. 2014;153(1):220-232.

31. Asnake S, Teklehaymanot T, Hymete A, et al. Survey of medicinal plant used to treat malaria by Sidama People of Boricha District, Sidama Zone, South Region of Ethiopia. Evid Based Complement Alternat Med. 2016;2016:1-9.

32. Oliveira H, Kffuri C, Casali V. Ethnopharmacological study of medicinal plants used in Rosário. Brazilian Journal of Pharmacology. 2010;20(2):256-260.

33. Bieski I, Rios Santos F, Oliveira R, et al. Ethnopharmacology of medicinal plants of the pantanal region (Mato Grosso, Brazil). Evid Based Complement Alternat Med. 2012;2012:1-36.

34. Brito M, Senna-Valle L. Diversity of plant knowledge in a 'Caiçara' community from the Brazilian Atlantic Forest coast. Acta Bot Bras. 2012;26(4):735-747.

35. Meragiaw M, Asfaw Z, Argaw M. The status of ethnobotanical knowledge of medicinal plants and the impacts of resettlement in Delanta, Northwestern Wello, Northern Ethiopia. Evid Based Complement Alternat Med. 2016;2016:1-24.

36. Hassan-Abdallah A, Merito A, Hassan S, et al. Medicinal plants and their uses by the people in the Region of Randa, Djibouti. J Ethnopharmacol. 2013;148(2):701-713.

37. Garcia D, Domingues M, Rodrigues E. Ethnopharmacological survey among migrants living in the Southeast Atlantic Forest of Diadema, São Paulo, Brazil. J ethnobiol ethnomed.2010;6(1):29.

38. Maynard L, Santos K, Cunha P, et al. Chemical composition and vasorelaxant effect induced by the essential oil of Lippia alba (Mill.) N.E. Brown. (Verbenaceae) in rat mesenteric artery. Indian J Pharmacol. 2011;43(6):694-698.

39. Hatano V, Torricelli A, Giassi A, et al. Anxiolytic effects of repeated treatment with an essential oil from Lippia alba and (R)-(-)-carvone in the elevated T-maze. Braz J Med Biol. 2012;45(3):238-243.

40. Pascual M, Slowing K, Carretero M, et al. Antiulcerogenic activity of Lippia alba (Mill.) N. E. Brown (Verbenaceae). Farmaco. 2001;56(7):501-504.

41. Farias D, Souza I, Viana M, et al. Antibacterial, antioxidant, and anticholinesterase activities of plant seed extracts from Brazilian semiarid region. Biomed Res Int. 2013;2013:1-9. 
42. Lopes A, Magalhães T, Uchôa D, et al. Afrormosin, an Isoflavonoid from Amburana cearensis A. C. Smith, Modulates the Inflammatory Response of Stimulated Human Neutrophils. Basic Clin Pharmacol Toxicol. 2013;113:363-369.

43. Lanzotti V. The analysis of onion and garlic. $\ J$ Chromatogr $A$ 2006;1112:3-22.

44. Corzo-Martinez M, Corzo N, Villamiel M. Biological properties of onions and garlic. Trends Food Sci Technol. 2007;18(12):609-625.

45. Hara Y, Noda A, Miyata S, et al. Effects of Aged Garlic Extract on Left Ventricular Diastolic Function and Fibrosis in a Rat Hypertension Model. Experiment Anim. 2013;62(4):305-310.

46. Ahlawat K, Khatkar B. Processing, food applications and safety of Aloe veraproducts: a review. J Food Sci Technol. 2011;48(5):525-533.

47. Beyaa W, Davidsona B, Erlwangera K. The effects of crude aqueous and alcohol extracts of Aloe vera on growth and abdominal viscera of suckling rats. Afri J Tradit Complement Altern Med. 2012;9(4):553-560.

48. Lee Y, Ju H, Kim Y, et al. Enhancement of anti-inflammatory activity of Aloe vera adventitious root extracts through the alteration of primary and secondary metabolites via salicylic acid elicitation. PloS one 2013;8(12):1-13.

49. Figueredo F, Ferreira E, Lucena B, et al. Modulation of the antibiotic activity by extracts from Amburana cearensis AC Smith and Anadenanthera macrocarpa (Benth) Brenan. Biomed Res Int. 2013;2013:1-5

50. Sá M, Ralph M, Nascimento D, et al. Phytochemistry and preliminary assessment of the antibacterial activity of chloroform extract of Amburana cearensis (Allemão) AC Sm against Klebsiella pneumoniaeCarbapenemase-Producing Strains. Evid Based Complement Alternat Med. 2014;2014:1-7.

51. Pepato M, Keller E, Baviera A, et al. Anti-diabetic activity of Bauhinia forficata decoction in streptozotocin-diabetic rats. $J$ Ethnopharmacol. 2002;81:191-197.

52. Menezes F, Minto A, Ruela H, et al. Hypoglycemic activity of two Brazilian Bauhinia species: Bauhinia forficata L. and Bauhinia monandra Kurz. Braz J Pharmacog. 2007;17(1):8-13.

53. Khalil N, Pepato M, Brunetti I. Free radical scavenging profile and myeloperoxidase inhibition of extracts from antidiabetic plants: Bauhinia forficata and Cissus sicyoides. Biol Res. 2008;41:165-171.

54. Gayathri K, Jayachandran K, Vasanthi HR, et al. Cardioprotective effect of lemon grass as evidenced by biochemical and histopathological changes in experimentally induced cardiotoxicity. Hum Exp Toxicol. 2011;30(8):1073-1082

55. Shah G, Shri R, Panchal V, et al. Scientific basis for the therapeutic use of Cymbopogon citratus stapf (Lemon grass). J Adv Pharm Technol Res. 2011;2(1):3-8.

56. Mirghani M, Liyana Y, Parveen J. Bioactivity analysis of lemongrass (Cymbopogan citratus) essential oil. Int Food Res J. 2012;19(2):569-575.

57. Olorunnisola S, Asiyanbi H, Hammed A, et al. Mini Review Biological properties of lemongrass: An overview. Int Food Res J. 2014;21(2):455-462.

58. Nascimento F, Cruz G, Pereira P, et al. Ascitic and solid Ehrlich tumor inhibition by Chenopodiumambrosioides L. treatment. Life Sci J. 2006;78(22):2650-2653.

59. Ibironke G, Ajiboye K. Studies on the anti-inflammatory and analgesic properties of Chenopodium ambrosioides leaf extract in rats. Int $J$ Pharmacol. 2007;3(1):111-115.

60. Sousa Z, Oliveira F, Conceição A, et al. Biological activities of extracts from Chenopodium ambrosioides Lineu and Kielmeyera neglecta Saddi. Ann Clin Microbiol Antimicrob. 2012;11(20):1-7.
61. Avila-Blanco M, Rodríguez M, Moreno Duque J, et al. Amoebicidal activity of essential oil of Dysphania ambrosioides (L.) Mosyakin \& Clemants in an amoebic Liver abscess hamster model. Evid Based Complement Alternat Med. 2014;2014:1-7.

62. Savino F, Cresi F, Castagno E, et al. A randomized double-blind placebo-controlled trial of a standardized extract of Matricariae recutita, Foeniculum vulgare and Melissa officinalis (ColiMil) in the treatment of breastfed colicky infants. Phytother Res. $2005 ; 19(4): 335-340$.

63. Kaur G, Arora D. Bioactive potential of Anethum graveolens, Foeniculum vulgare and Trachyspermum ammi belonging to the family UmbelliferaeCurrent status. J Med Plant Res. 2010;4(2):87-94.

64. Badgujar S, Patel V, Bandivdekar A. Foeniculum vulgare Mill : A review of its botany, phytochemistry, pharmacology, contemporary application and toxicology. Biomed Res Int. 2014;2014:1-32.

65. Hennebelle T, Sahpaz S, Joseph H, et al. Ethnopharmacology ofLippia alba. J Ethnopharmacol. 2008;116(2):211-222.

66. Ara N, Amran M, Wahid M, et al. In vitro antimicrobial and citotoxic of leaves and flowers extracts from Lippia alba. Pak J Biol Sci. 2009;12(1):87-90.

67. Reis L, Pardo P, Oba E, et al. Matricaria chamomilla $\mathrm{CH}_{12}$ decreases handling stress in Nelore calves. J Vet Sci. 2006;7(2):189-192.

68. Srivastava J, Shankar E, Gupta S. Chamomile: A herbal medicine of the past with bright future. Mol Med Rep. 2010;3(6):895-901.

69. Zangeneh Z, Minaee B, Amirzargar A, et al. Effects of chamomile extract on biochemical and clinical parameters in a rat model of polycystic ovary syndrome. J Reprod Infertil. 2010;11(3):169-174.

70. Ranjbar A, Mohsenzadeh F, Chehregani A, et al. Ameliorative effect of Matricaria chamomilla L. on paraquat: Induced oxidative damage in lung rats. Pharmacognosy Res. 2014;6(3):199-203.

71. Pearson W, Fletcher R, Kott L, et al. Protection against LPS-induced cartilage inflammation and degradation provided by a biological extract of Mentha spicata. BMC Complement Altern Med. 2010;10:1-19.

72. Arumugam P, Ramesh A. In-vivo antioxidant effects of ethyl acetate fraction of Mentha spicata L. on 4-Nitroquinoline-1-Oxide Injected Mice. Iran J Pharm Res. 2011;10(4):787-793.

73. Tayarani-Najaran Z, Talasaz-Firoozi E, Nasiri R, et al. Antiemetic activity of volatile oil from Mentha spicata and Mentha piperita in chemotherapy-induced nausea and vomiting. Ecancermedicalscience. 2013;7:290.

74. Grover J, Khandkar S, Vats V, et al. Pharmacological studies on Myristica fragrans antidiarrheal, hypnotic, analgesic and hemodynamic (blood pressure) parameters. Methods Ind Exp Clin Pharmacol. 2002;24(10):675-680.

75. Chiu Y, Huang T, Chiu C, et al. Analgesic and antiinflammatory activities of the aqueous extract from Plectranthus amboinicus (Lour.) Spreng. Both In Vitro and In Vivo. Evid Based Complement Alternat. 2012;2012:1-11.

76. Ravikumar V, Dhanamani M, Sudhaman T. In-vitro anti- inflammatory activity of aqueous extract of leaves of Plectranthus amboinicus (Lour.) Spreng. Anc Sci Life. 2014;28(4):7-9.

77. Koti B, Gore A, Thippeswamy AH, et al. Alcoholic leaf extract of Plectranthus amboinicus regulates carbohydrate metabolism in alloxan-induced diabetic rats. Indian J Pharmacol. 2011;4(3):286-290.

78. El-hawary S, El-sofany R, Abdel-Monem A, et al. Polyphenolics content and biological activity of Plectranthus amboinicus (Lour.) spreng growing in Egypt (Lamiaceae). Phcog J. 2012;4(32):45-54.

79. Oliveira F, Torres A, Gonçalves T, et al. Efficacy of Plectranthus amboinicus (Lour.) Spreng in a murine model of methicillinresistant Staphylococcus aureus skin abscesses. Evid Based Complement Alternat Med. 2013;2013:1-9. 
80. Chang J, Chengv C, Hung L, et al. Potential Use of Plectranthus amboinicus in the treatment of rheumatoid arthritis. eCAM. 2010;7(1):115-1120.

81. Câmara C, Nascimento N, Macêdo-Filho C, et al. Antispasmodic effect of the essential oil of Plectranthus barbatus and some major constituents on the guinea-pig ileum. Planta Med. 2003;69(12):1080-1085.

82. Lukhoba C, Simmonds M, Paton A. Plectranthus: A review of ethnobotanical uses. J Ethnopharmacol. 2006;103:1-24.

83. Maioli M, Alves L, Campanini A, et al. Iron chelating-mediated antioxidant activity of Plectranthus barbatus extract on mitochondria. Food Chem. 2010;122(1):203-208.

84. Murthy K, Veigas V, Murthy U. Study on wound healing activity of Punica granatum peel. J Med Food. 2004;7(2):256-259.

85. Lansky E, Newman R. Punica granatum (pomegranate) and its potential for prevention and treatment of inflammation and cancer. $J$ Ethnopharmacol. 2007;109(2):177-206.

86. Abdollahzadeh S, Mashouf R, Mortazavi H, et al. Antibacterial and antifungal activities of Punica granatum peel extracts against oral pathogens. J Dent (Tehran). 2011;8(1):1-6.

87. Miranda-Cruz E, Espinosa-Moreno J, Centurión-Hidalgo $\mathrm{D}$, et al. Actividad antimicrobiana de extractos de Psidium friedrichsthalianum L., Pterocarpus hayesii L., Tynanthus guatemalensis L. y Spondias purpurea L. Bol Latinoam Caribe Plant Med Aromat. 2012;11(4):354-361.

88. Gregoris E, Pereira Lima G, Fabris S, et al. Antioxidant properties of Brazilian tropical fruits by correlation between different assays. Biomed Res Int. 2013;2013:1-8.
89. Lima J, Martins D, De Souza P. Experimental evaluation of stem bark of Stryphnodendron adstringens (Mart.) Coville for antiinflammatory activity. Phytother Res. 1998;12:218-220.

90. Audi E, Eduardo C, Toledo M, et al. Biological activity and quality control of extract and stem bark from Stryphnodendron adstringens. Acta Farm Bonaerense. 2004;23(3):328-333.

91. Costa M, Ishida K, Kaplum V, et al. Safety evaluation of proanthocyanidin polymer-rich fraction obtained from stem bark of Stryphnodendron adstringens (Barbatimao) for use as a pharmacological agent. Regul Toxicol Pharmacol. 2010;58(2):330-335

92. Ishida K, Rozental S, De Mello J, et al. Activity of tannins from Stryphnodendron adstringens on Cryptococcusneoformans: effects on growth, capsule size and pigmentation. Ann Clin Microbiol Antimicrob. 2009;8:29.

93. Cavalcante G, Resende R, Leite J, et al. Potential of ethyl acetate fractions of Stryphnodendron adstringens shells and fruit extracts of Caesalpinia ferrea to control bacterial leaf speck and on the potentiation of defense enzymes in tomato. Trop Plant Pathol. 2014;39(4):267-274.

94. Souza P, Elias S, Simeoni L, et al. Plants from brazilian cerrado with potent tyrosinase inhibitory activity. PloS one. 2012;7(11):1-7.

95. Costa M, Palazzo de Mello J, Kaneshima E, et al. Acute and chronic toxicity of an aqueous fraction of the stem bark of Stryphnodendron adstringens (Barbatimão) in Rodents. Evid Based Complement Alternat Med. 2013;2013:9. 